\title{
Preparing Student Teachers to Teach Mathematics with GeoGebra
}

\author{
Nurhashimah Za'ba, Zaleha Ismail ${ }^{*}$, Abdul Halim Abdullah \\ Faculty of Social Sciences and Humanities, Universiti Teknologi Malaysia, Malaysia \\ Received January 22, 2020; Revised April 1, 2020; Accepted April 21, 2020
}

Copyright $\odot 2020$ by authors, all rights reserved. Authors agree that this article remains permanently open access under the terms of the Creative Commons Attribution License 4.0 International License

\begin{abstract}
This paper shares the working process that has been carried out in a postgraduate mathematics teacher education course known as Technology in Mathematics Education. Many efforts around the world attempt to train student teachers on the use of technology without giving much attention to appropriate instructional model. Our work in this area gave special considerations in integrating technological pedagogical and content knowledge (TPACK) in training student teachers to teach mathematics with Geogebra, a dynamic multi-purpose mathematics software. Specifically, this paper shares the (1) theoretical background that guides the structure of the course, (2) the course methodology, which includes teaching and learning activities to prepare 15 student teachers to teach mathematics with GeoGebra and (3) the learning outcomes of the 14 weeks course. The design for integrating teachers' knowledge of subject matter, and teaching with subject matter with the development of TPACK was discussed. Among the GeoGebra activities emphasized are (1) creating geometric constructions and exploring their mathematical properties (2) exploring ratio and proportions, (3) applying sliders to modify parameters, (4) visualizing algebraic input and functions, and (5) modelling and constructing transformations in geometric designs and animations. Elements of TPACK were traced as the student teachers carried out experimental teaching with GeoGebra in schools as part of the requirement of the course. The Malaysian mathematics curriculum in its latest development has incorporate GeoGebra activities in the textbooks. Hopefully with the course we described in this paper, not only more teachers are willing to adopt GeoGebra but to integrate GeoGebra effectively in their practices.
\end{abstract}

Keywords Technological Pedagogical and Content Knowledge, Mathematics Education, Postgraduate Level, GeoGebra, Technology Integration

\section{Introduction}

Successful integration of technology in teaching occurs when teachers are able to use technology tools to help them obtain information, analyze and synthesize the information, and present it to students professionally [1]. In Malaysia, various efforts have been made to improve, maintain and enhance the mathematics education progress with the development of the technological world today. In National Education Blueprint, the Ministry has spent more than RM6 billion on Information and Communication Technology (ICT) to expand capacity and allow for more customized learning [2]. The funds went towards additional computer labs in every school and delivery of laptops for each teacher in schools. Mathematics teachers are then encouraged to teach mathematics using the latest technology to foster students mathematical thinking. A software known as GeoGebra, is one of the most effective educational software in teaching and learning of mathematics and is being the most highlighted technology medium in Malaysian mathematics curriculum. The new secondary mathematics syllabus also embed GeoGebra activities in the latest textbooks [3].

Teaching mathematics with GeoGebra requires reconstruction of mathematical knowledge, pedagogical and technological knowledge as [4] said that certain software has a potential in treating certain selections of mathematics topics or support certain instructional approaches. TPACK came as a framework to understand teachers' knowledge toward technology integration in teaching and learning [5]. Thus this type of knowledge should be integrated in courses for teacher training.

With the rapid changes in ICT, mathematics teachers are encouraged to study at the postgraduate level, so they can enhance their teaching to become more proficient and highly trained with the current practices. Numerous efforts had been made through postgraduate teacher education programs to ensure mathematics teachers are adequately trained to develop TPACK. 
Traditionally, mathematics teacher education programs have prepared on one course focuses on learning about technology. The challenge is that the student teachers will achieve proficiency in technology integration prior to the completion of their course. However, the problem in most of those courses is they were not focusing on developing mathematics TPACK, instead, they were focusing on increasing ICT skills. Based on [6], there is no common structure for ICT courses in public universities in Malaysia, especially for teacher training to produce highly-trained teachers who will be able to teach with ICT in schools. [7] suggested, to develop TPACK, a concern about teaching with technology should be included in the approaches of the course.

This paper provides the working process that has been done by the authors in a postgraduate mathematics teacher education course, Technology in Mathematics Education. The authors want to share their works on teaching postgraduate student teachers to teach mathematics with GeoGebra throughout the course. Specifically, this paper shares (1) the theoretical background that guides the structure of the course, (2) the course methodology which are teaching and learning activities to prepare student teachers to teach mathematics with GeoGebra and (3) the learning outcomes of the course. This sharing views the goal of this design holds for integrating teachers' knowledge of subject matter, and teaching with subject matter with the development of knowledge of technology (TPACK).

\section{Theoretical Background}

Constructivists believe that knowledge is constructed by individuals based on their experiences. [8] explained the view of constructivism about knowledge, learning, teaching and relationship about the constructs. He stated that individuals are assumed to construct their own understandings and meanings by connecting to their existing knowledge with new receiving knowledge and experiences. As the theory, constructivism is where a process of learning occurred caused by adaptive activities in receiving knowledge that required building conceptual structures and self-regulation through reflection and abstraction. Basically, learning is an active process of knowledge construction influenced by how individual interacts with and interprets new ideas and situations. [9] argued that when teachers are adapting new instructional practices, they are experiencing a process of assimilation and accommodation that results in changes in their thinking. This process occurs during the development of TPACK to teach with technologies among mathematics teachers.

The course is guided by a framework of "Knowledge Growth in Teaching" described by [10]. This conceptual framework highlighted the integration of five domain of knowledge that impact pedagogical content knowledge (PCK) - schools, learners, subject matter, curriculum, and pedagogy including PCK. Investigation of PCK research studies provides some insight into the preparation of postgraduate students to develop TPACK. In postgraduate teacher education course, student teachers are prepared with skills in using software technology and abilities to engage students in learning specific topics in mathematics using the technology (GeoGebra) and other supported technological resources (tutorials videos, online manual, video cam application etc). This conceptual framework is developed primarily from a constructivist epistemology proposing the outcome of knowledge, skills and abilities to support teachers in making decision when confronted with many instructional decisions that occur during teaching in the classroom.

In postgraduate teacher education course, we expected that student teachers would involve in constructing their own knowledge of teaching by connecting their existing beliefs, goals, knowledge, and thinking with new knowledge in instructional settings. With respect to teaching with technology, technology education course typically provides a lesson about technology with a unit or discussion on teaching with technology and a requirement that student teachers design lessons to teach with technologies. The experiences during the course is what the development of new knowledge, which is believed as TPACK, is involved. [7] stated that as learners, teachers are involved in integrating new knowledge received from the course into their prior understanding for teaching the content. From constructivist perspectives, their learning is largely originated from personal experiences, and their understanding depend on what they have been taught during the course. In this case, the hope is that their beliefs, knowledge and thinking would grow through the course experiences and instructional practice. These experiences require a process of thinking and decision making of the teachers.

Overall reviews on teacher thinking process related to instructional practice have identified three important components: planning during the preactive (prior to teaching) stage [11], monitoring and regulating during the interactive (teaching) stage [12], and assessing and revising in the postactive (after teaching) stage [13]. These components found in the teacher metacognitive framework [14]. Reference [15] claimed that the development of an integrated knowledge structure for typical expert teachers requires experiences focused on an integration of these teaching stages. In postgraduate level course, student teachers must be challenged to reconsider their subject matter content (that they learned from graduate level or teaching experiences) and the impact of technology on the development of that subject itself as well as on teaching and learning that subject.

While [11-15] explanations provide more clarify to teachers thinking about instruction, reference [16] argued that differences could be occurred in teachers' actions when teaching mathematics with various technologies. [16] described such differences in his innovation-decision process framework when working with innovation, 
whether to accept or reject a particular innovation. Our study refers to this framework to understand decision-making experiences that provide the critical actions in support of teachers' knowledge, belief, goals and thinking for the growth and maturation of teachers' professional development.

\section{Course Methodology}

\section{A. The course}

The postgraduate teacher education course for this study held in a public university in Malaysia, met for 3 hours at every Wednesday, every week in first semester of 2017/2018. There are 15 weeks for one semester and one mid-semester break at Week 6. The learning lessons specifically emphasized on teacher professional development toward appropriate teaching with nowadays technological instructional tools or software in mathematics curriculum. GeoGebra was chosen as the software applied in this course as it is being the most highlighted technology medium in Malaysian mathematics curriculum. The course originally discussed the issues of computer applications in mathematics education with emphasis on its special role in teaching and learning processes. The authors, one is a mathematics educator with many years of experiences and another is an educator assistant. Mathematics educator had previously taught the course form past semesters and had years of teaching experiences. In that semester, student teachers learned a teaching and learning lessons with GeoGebra to develop their TPACK.

\section{B. Students Background}

15 postgraduate students are enrolled in this course; most of them are mathematics teachers and still teaching mathematics in schools, while, the others are fresh graduate who continue their study to postgraduate level. We are informed that the students who are mathematics teachers are still teaching while attending the course. These students had previously earned at least a Bachelor's degree including subject matter requirements for their proposed teacher areas. There are three distinct degree streams within the students: science mathematics, mathematics education and education. All degrees are accredited. Most students have already specialized in science, mathematics, technology and education. The descriptions of the students' background are as follow:

[1] Ten of them are mathematics teachers who have teaching experiences between 3 to 15 years and five are fresh graduate

[2] Six of them from bachelor of education and nine from bachelor of science mathematics
[3] Majority are familiar with computers and technology application

[4] The students are taking the course at second or third semester of their postgraduate study

Understanding the differences, we do not find it as problems to us because we consider their differences and degree specialisms are still in the set. We believe their differences is an aid to them to cooperate with each other in order to increase their professional development into a wider technology and computer integration.

\section{Teaching and Learning Activities}

The course used a multi-dimensional approach for teaching and learning activities. There are so many teaching approaches include lectures, demonstrations, discussion, laboratory work and academic forum. In the course, we let student teachers did hands-on experiences, discussion and cooperative learning, and independent study on applying technology in teaching and learning mathematics.

For the first two weeks of the course lessons, we gave a brief explanation about the course outline to the students. Firstly, the students will be explained the synopsis of the course, the learning outcome and the first introduction lessons about TPACK, nowadays open source movement and GeoGebra. We incorporate with the students upon understanding of the potential for learning technologies to work as tool to teach mathematics.

Second sessions, we gave lectures and demonstrations on teaching and learning mathematics with GeoGebra. The next several weeks before semester break, the students would be taught a basic use of GeoGebra and exploring its applications. Teaching and learning with GeoGebra can be many ways, include demonstrations, explorations and modelling, constructions of mathematical objects and experimental work [17]. For the course, the educator teach and demonstrate the students to (1) create drawings and geometrics constructions such as rectangle, square, parallelogram, equilateral triangle and regular polygons, (2) explore ratio and proportions, (3) applying sliders to modify parameters, (4) visualize algebraic input and functions, and (5) model and create transformation in geometric design and animation, using GeoGebra application. During the activities, we guide our students to always analyse every activity by comparing the results of learning the mathematical concept using GeoGebra with other conventional methods. Through these activities, the students are focused on making decision about issues of teaching with technology.

After semester break, the instructions are more focus on applying GeoGebra in problem solving and designing technology based lessons. The educator gives mathematics problems and along with the students, we let them discuss to solve the problems within their own group. Example of the problems as below: 
- $\quad$ Find the center of a circle without and with GeoGebra

- Imran who stays in Trabzon heard that his friend in Ankara injured himself in a car accident. Imran would like to bring a walking stick 42 inches long by train to his friend. The train service would only allow passengers to carry object that is not more than 36 inches long. How can he package the walking stick?

- $\quad$ Arrange 5x5 points on a piece of paper. Draw 5 circles that pass on at least one point. All the 5 circles pass through all 25 points. Do this task without GeoGebra and then with GeoGebra.

- Ibrahim's mother is critically ill and being hospitalized. At that time in their piggy bank, Ibrahim have 6050 cents coins and 2825 cents coins while his younger brother has 3050 cents coins and 2025 cents coins and 100 cents coins. While their mother is in the hospital, Ibrahim give away for sadaqah 50cents per day while his younger brother gives 25 cents per day. On what day will both brothers have same amount of money left?

- Hasbul is 8 years older than Nurul Ain. Four years ago, Hasbul age is 5 times Nurul Ain. How old are they?

- A factory owner Mr Mok makes drinking glasses of volume $300 \mathrm{~cm} 3$ in the shape of right circular cylinder open at the top. Find the dimensions which use the least material.

The student teachers explore a variety of mathematics problems that can be solved using GeoGebra and might be considered in the curriculum. We are also making some discussions with the students to compare teaching strategies which are suitable with the problems using or not using GeoGebra. These activities were designed to help student teachers to become proficient with the use of GeoGebra application. Moreover, through these activities, the student teachers are focused on thinking and decision making about issues of teaching with GeoGebra. We focus on letting student teachers to design GeoGebra mathematical problems and worksheets, so it might help them to design lessons for the main learning outcomes of the course.

\section{Outcomes}

We expect the learning outcomes of the course can be analysed through a group project assignment that we designed for the student teachers. The student teachers must complete a group project where the groups are expected to prepare GeoGebra mathematics teaching lesson plan, go to school to teach the lessons to small group of students outside from the class times. From the beginning, the 15 student teachers have been divided into five groups with three group members in each group. Each group had at least one mathematics teacher as a member so that it is convenient to conduct geogebra lessons in schools. After the semester break, the course is more in depth into providing some instructions and supporting for writing lesson plans and teaching.

TPACK can be assessed from analyzing the designed lesson plan [18]. The lessons must demonstrate a clear subject matter of mathematics lesson, teaching strategies to mathematics learning, designed GeoGebra techniques that can support transfer of knowledge, support together the teaching strategies to the lesson objectives, align GeoGebra techniques to the lesson objectives, support GeoGebra to the teaching strategies and fit together within mathematical content, teaching strategies and GeoGebra techniques. For early assessment, at Week 8 of the course, the groups must present their lesson plan (using PowerPoint) in the class so they can get some feedback and advices for improvements of their plans before they teach the lessons to the students.

Starting week 9 until week 12, the groups were allowed to teach the lessons that they designed and planned to the students at the schools that they have chosen. The lessons must span around six to eight hours of teaching and learning activities with integration of GeoGebra. The student teachers have to do a full report which compiled their experiences and learning for this project. At week 15, the report must be submitted to be assessed. The teaching activities that took place in schools were videotaped so that they can reflect on the teaching experiences in which they consider how to improve the lesson and their own teaching and put in the report. Assessment through teaching practices focus on the teacher students thinking processes to consider the multitude of variables that affecting the success of a lesson in guiding students' progress toward the lesson objectives. By the end of the semester, all groups had accomplished in working on the group assignment.

From our observations based on their videos and written reports, both the teachers and students were very comfortable working with geogebra in the mathematics classrooms. The lessons were conducted in the school computer labs such that students could worked on hands-on activities. They ensure that in their teaching not only they introduced the technical aspects of geogebra but also highlighted the mathematics concepts behind the mathematical constructions. For example in teaching translation, by constructing an object being translated through a vector, students can experiment the constructions to discover the properties of translation. Further in the follow up activity, they could apply this concept of translation along with rotations, scaling and reflection, creative constructions such as an animated fish or moving airplane were succesfully achieved. This kind of enriched teaching that go beyond the teaching of concepts required teachers to have knowledge not only on mathematical content and pedagogy but also the blending of pedagogical content knowledge which is an important component of TPACK. 


\section{Conclusions}

The process of TPACK development is the process of how TPACK is gained or developed progressively to understand the relationship between the integration of new technology in teaching mathematics among teachers and their professional development. Using GeoGebra as the technology to be integrated, our aim is to understand the process of gaining TPACK in depth in the postgraduate technology mathematics education course. As the aim of this paper is merely sharing our efforts in training to teach mathematics with Geogebra, we keep the complete analysis of the TPACK development in other coming publication. As such, for ongoing professional development, our investigation through technology mathematics education course would led to the goal of the community to see technology can be integrated effectively in school practices. The Malaysian mathematics curriculum in its latest development has incorporate geogebra activities in the textbooks. Hopefully with the couse we described in this paper, more teachers are willing to adopt geogebra effectively in their practices.

\section{Acknowledgements}

The authors acknowledge Universiti Teknologi Malaysia and the European Commission for the financial support given in making this study possible through the research grant Vote No. R.J130000.7353.4B393.

\section{REFERENCES}

[1] National Council of Teachers of Mathematics, "Principles and standards for school mathematics," pp. Reston, Va: NCTM, 2000.

[2] Ministry of Education, Preliminary Report Malaysia Education Blueprint 2013-2025, Putrajaya: Malaysia Education Blueprint, 2012.

[3] Ministry of Education, Form One Mathematics textbook, Johor: Pelangi Sdn. Bhd., 2016.

[4] J. Preiner, Introducing Dynamic Mathematics Software to Mathematics Teachers: the Case of GeoGebra, Doctoral philosophy, University of Salzburg, Salzburg., 2008.

[5] P. Mishra and M. J. Koehler, "Technological pedagogical content knowledge: A framework for teacher knowledge," Teachers College Record, pp. 108 (6), 1017-1054, 2006.

[6] S. Sulaiman, M. S. Norhaziah, I. Mohamad, M. S. Amily, N. Noriza and B. Razana, "The Development of The Pedagogical Content Knowledge (PCK) Standard for Malaysian ICT Teachers," Journal of ICT in Education , pp. 1, 29-41, 2014.

[7] M. Niess, "Preparing teachers to teach science and mathematics with technology: Developing A technology pedagogical content knowledge," Teaching and Teacher Education, pp. 509-523, 2005.

[8] K. Yilmaz, "Constructivism: Its Theoretical Underpinnings, Variations, and Implications for Classroom Instruction," Educational Horizons , pp. 86(3), 161-172, 2008.

[9] B. Shreiter and P. Ammon, Teachers' thinking and their use of reading contracts, Paper presented at the annual meting of the American Educational Research Association, San Francisco, 1989.

[10] L. S. Shulman, "Those who understand: Knowledge growth in teaching," Educational Researcher, pp. 15(2), 4-14, 1986.

[11] C. M. Clark and R. J. Yinger, "Teachers' thinking," in Research on teaching, Berkeley, CA, McCutchan, 1979, pp. 231-263.

[12] C. M. Clark and P. L. Peterson, "Stimulated-recall," in Flexibility in teaching: An excursion into the nature of teaching and training, New York, Longman, 1981.

[13] D. D. Ross, "First steps in developing a reflective approach," Journal of Teacher Education, pp. 40(2), 22-30, 1989.

[14] A. F. Artzt and E. Armour-Thomas, "Mathematics teaching as problem solving: A framework for study teacher metacognition underlying instructional practice in mathematics," Instructional Science, pp. 26, 5-25, 1998.

[15] M. L. Niess, "A Model for Integrating Technology in Preservice Science and Mathematics Content-Specific Teacher Preparation," School Science and Mathematics, pp. 101(2), 57-110, 2001.

[16] E. M. Rogers, Diffusion of innovations, New York: Free Press, 1983.

[17] I. Zilinskiene and M. Demirbilek, "Use of GeoGebra in Primary Math Education in Lithuania: An Exploratory Study from Teachers' Perspective," Informatics in Education, pp. 14(1), 127-142, 2015.

[18] D. D. Agyei and J. Keengwe, "Using Technology Pedagogical Content Knowledge Development to Enhance Learning Outcomes," Educ Inf Technol, pp. 19, 155-171, 2014. 